\title{
Miscellany
}

\section{The McHarg Prize}

The Scottish Division of the Royal College of Psychiatrists offer a prize of $£ 100$ to a trainee who is working in Scotland and who is of senior registrar or registrar grade. Candidates for the prize are invited to submit essays or scientific papers based on their own studies or their original work. It is expected that submissions will range from essays based on literature review to descriptions of clinical work or research in the field.

All entries will be considered by a panel set up by the Scottish Executive Committee and it is intended that the successful candidate will be invited to present his or her paper to a meeting of the Scottish Division.

Submissions must be returned before 1 December 1989 to Dr R. G. McCreadie, Honorary Secretary, Scottish Division, Crichton Royal Hospital, Dumfries, DG1 4TG.

\section{New appointments}

Dr Ashoka Jahnavi Prasad, Consultant Psychiatrist, Claybury Hospital, Woodford Green, Essex has been appointed Professor of Psychiatry at St Mary's University, Halifax, Canada and will be taking up his appointment in April 1990.

Marjorie Wallace, formerly a campaigning journalist with Times Newspapers, has been appointed
Director of SANE (Schizophrenia: A National Emergency).

\section{Neuroscience research centre}

Construction of the Edward Robinson/MRC Pharmacology Building at Oxford began recently. In October 1987 the Squibb Corporation entered a long-term agreement with Oxford University to fund the establishment of a research facility for the Department of Pharmacology and to endow the facility's operating costs. In addition, Squibb agreed to fund individual neuroscience projects proposed by the Department in areas such as degenerative diseases of the central nervous system.

\section{London flat to rent}

A flat in Hampstead will be available to a visiting faculty member or other professional person from 25 September 1989 until early July 1990 at a rent of $£ 600$ per month, exclusive of utilities; non-smoker preferred. The flat has one bedroom, sitting room, central heating, and all modern conveniences. The tenant would have use of the garden which opens onto the woods of the Heath. Please apply to: Dr Deborah Weiner, 2537 Overhill Lane, Davis, California 95616, USA (telephone 9167531004 or 916753 9051).

\section{Forthcoming events}

The Royal Society of Medicine will be holding the next meeting of the Forum on Clinical Pharmacology and Therapeutics entitled 'The Anxiolytic Jungle: Where Next?' on 6 October 1989. Registration fees: £35 (non-members); $£ 25$ (members) - to include coffee, lunch and tea. The meeting has Section 63 approval. Further information: Nicole Aaron, The Royal Society of Medicine, 1 Wimpole Street, London W1M 8AE(telephone 014082119 , extension 301).

A study day entitled 'The Mind Body Problem' exploring the interface between psychotherapy and physical medicine is to be held at the Freudenberg
Postgraduate Medical Centre, Netherne Hospital on 12 October 1989. Contributors will include the Medical Director of the Bristol Cancer Centre. For information sheet and further details: The Secretary to Dr I. F. Macilwain, Netherne Hospital, PO Box 150, Coulsdon, Surrey CR3 1YE.

A conference entitled 'Practical Approaches to Alcohol and Ofiending: Politics, Policy \& Prevention' will be held at Leicester Polytechnic from 14-15 September 1989. Fees: $£ 125$ full rate; $£ 95$ students and voluntary. agencies (includes refreshments, meals and accommodation). Further information: Alcohol \& Offending Conference, 20 College Avenue, Leicester LE2 0JF. 
Papers are invited for the Seventh Annual Meeting of the Society for Psychotherapy Research (UK) to be held at the Raven Hall Hotel, Ravenscar, North Yorkshire from 1-4 April 1990. Abstracts (500 words maximum) should be sent to: Dr Mike Startup, MRC/ESRC SAPU, Department of Psychology, The University, Sheffield S10 2 TN. Deadline for submissions is 15 November 1989.

A seminar entitled Crisis and Consequence will be held at The Priory Hospital on 5 October 1989 (2 p.m.4.30 p.m.). Topics: Acute Stress Reactions, Suicide and Psychiatric Emergencies, Crisis Intervention in Alcohol Dependence, and Management of Disasters: The Zeebrugge Experience. Further details: The Medical Director, The Priory Hospital, Priory Lane, London SW15 5JJ.

The First European Conference on Residential Care entitled 'Innovations in Residential Care' will be held from 30 November-2 December 1989 at De Haan (Belgium). It aims to give a general view of new residential care facilities and approaches for children with severe psycho-social problems, young delinquents and young addicts. Further details and application forms: Anne Vanden Berge, KU Leuven, Afdeling Orthopedagogiek, Vesaliusstraat 2, 3000 Leuven, Belgium.

The 6th National Lesbians in Health Care Conference entitled 'Lesbians and Mental Health' will be held on 9 December 1989 at Wesley House, Wild Court, Kingsway, London WC2. Further information: Edwina, Hoxton Health Collective, 1 Arden House, Pitfield Street, London N1.

The Lantern Trust will be holding a series of weekend courses for caregivers of people living with HIV infection or AIDS on 16/17 September, 14/15 October, 18/19 November, 9/10 December 1989 and 13/14 January, 10/11 February, 10/11 March, 7/8 April, 12/13 May, 9/10 June and 7/8 July 1990 at West Essex Medical Centre, St Margaret's Hospital, Epping, Essex. Cost for each course: $£ 95$ (including coffee, lunch, tea and resource pack). Further information: Cyril Ives, Co-ordinator, The Lantern Trust, 72 Honey Lane, Waltham Abbey, Essex EN9 3BS.

The Monaco International Talks entitled 'Man and His Pain' will be held from 22-25 November 1989. Further information: Les Entretiens Internationaux de Monaco, 12 av. d'Ostende, MC 98000, Monaco.

The Association for Psychoanalytic Psychotherapy in the NHS (APP) and the Society of Psychoanalytic Psychotherapists (SPP) will be holding a two day work.ing conference on 25 and 26 November 1989 at the London Business School, Regents Park, London NW1, entitled 'The Future Career of the Adult Psychoanalytic Psychotherapist in the NHS: The Way Ahead'. Conference fee: $£ 60$ before 25 October, $£ 70$ after 26 October 1989. Early registration advised. Further details: Mrs June Ansell, Conference Secretary, 87 St Mary's Mansions, St Mary's Terrace, London W2 1SY or Dr Anne Zachary, The Portman Clinic (telephone 01794 8262).

A one day symposium entitled Mind and Brain - The Science of Consciousness will be held at the Wolfson Lecture Theatre, The Institute of Psychiatry, De Crespigny Park, Denmark Hill, London SE5 8AF on 7 October 1989. Cost $£ 35$ including lunch. Cheques should be made payable to Dr Peter Fenwick at the above address (telephone 01703 5411). This symposium is intended for psychiatrists, psychologists, psychotherapists, neurophysiologists and all those interested in whether or not consciousness and mind can be described entirely by brain function. Speakers will include Professor Sir Brian Pippard, Professor Colin Blakemore, Professor Robert Morris, Dr Tim Shallice, Dr Max Velmans and Professor J. Gray. Early registration is advised.

The Institute of Psychiatry and the Bethlem Royal and Maudsley Hospitals will be holding an International Conference on Women and Mental Health on 23 and 24 October 1989. Opening address to be given by Harriet Harman MP. Course fee: $£ 60$ (including lunch and refreshments). Further information: Nadine Morgan, Conference Office, Institute of Psychiatry, De Crespigny Park, London SE5 8AF (telephone 01703 5411, extension 3170).

The Fifth World Congress of Biological Psychiatry will be held in Florence from 9-14 June 1991. Further information: ES Assistance, Via Napo Torriani, 30, 20124 Milan, Italy.

A conference entitled 'Drug Delivery and Drug Targeting Systems: Latest Advances' will be held from 30 November to 1 December 1989 at the Royal Lancaster Hotel, London. Further information: Renate Duke, IBC Technical Services Ltd, Bath House, 3rd Floor, 56 Holborn Viaduct, London EC1A 2EX(telephone 01 236 4080; fax: 01 489 0849).

The Second European Conference on Traumatic Stress entitled 'Traumatic Stress Reactions - Prevention, Coping and Treatment' will be held in Noordwijkerhout, The Netherlands, from 23-27 September 1990. Further information: Dr J. M. P. Weerts, c/o ICODO, Willem Barentstraat 31-C, 3572 PB Utrecht, The Netherlands. 
50th anniversary of the death of Sigmund Freud: The British Psycho-Analytical Society and the Psychoanalysis Unit of University College London will be holding a commemorative lecture by Peter Gay, Sterling Professor of History, Yale University, on 'Serious Jests: On Freud's Jokes' on 5 October 1989 at 7.45 p.m. at The Logan Hall, University of London, Institute of Education, 20 Bedford Way, London WC1. Admission free.

A day of lectures and discussions given by members of the British Psycho-Analytical Society entitled 'Sigmund Freud: 50 Years On. How Freud Lives on in My Work' will be held at the Institute of PsychoAnalysis on 23 September 1989. Fee for the day: $£ 18$ (includes coffee and afternoon tea). Admission by ticket only. Further information: The Hon. Secretary, Public Lectures Committee, The Institute of Psycho-Analysis, 63 New Cavendish Street, London W1M 7RD (telephone 01580 4952).

The Portman Clinic will be holding the 1989 Edward Glover Lecture to be given by Dr J. A. C. MacKeith on 'Why Confess' at 8.15 p.m. on 30 October 1989 at Peter Samuel Hall, Royal Free Hospital, London NW3. Admission by ticket (£3). Cheques payable to Hampstead Health Authority. Apply to: Mrs P. Harrington, Administrative Secretary, The Portman Clinic, 8 Fitzjohns Avenue, London NW3 5NA (telephone 01794 8262).

The WHO Collaborating Centre for Mental Heath Research and Training, Department of Psychiatry, Rawalpindi General Hospital, is organising the 8th International Psychiatric Conference at Islamabad from 11-14 December 1990. The theme will be 'Mental Health for All - All for Mental Health'. Further information:Professor Malik H. Mubasshar, Chairman, Organising Committee \& Director, WHO Collaborating Centre, Department of Psychiatry, Rawalpindi General Hospital, Rawalpindi, Pakistan.

A Symposium on Mental Retardation will be held on 4 October 1989. Topics will include organisation of services, community care, pharmacological approaches, and depression in the mentally handicapped. Approval under Section 63 is sought. Fee: $£ 10$ (inclusive of lunch). Further details: Dr E. M. R. de Saram, Whittington Hall Hospital, Old Whittington, Chesterfield, Derbyshire S41 9LJ.

St George's Hospital Medical School will be holding the Annual Course in Group Dynamics for Trainees in Psychiatry at the Freudenberg Postgraduate Centre, Coulsdon from 6.00 p.m. on 30 November until 2 December 1989 at 6.30 p.m. The course is approved under HM(67)27 and has been organised for trainees in psychiatry to have the opportunity for an experiential psychodynamic learning process. Fee: $£ 90$. Further details: Dr Stuart Lieberman, Senior Lecturer and Consultant Psychiatrist, St George's Hospital Medical School, Cranmer Terrace, Tooting, London SW17 0RE.

East Cumbria Health Authority will be holding a guest lecture on the afternoon of 12 September 1989. The main speaker will be Professor Schou from Denmark speaking on 'Lithium Prophylaxis: Recent advances and practical problems'. Further information: Dr D. P. Srinivasan, Consultant Psychiatrist, Garlands Hospital, Carlisle, Cumbria CAl 3SX (telephone 0228 31081).

The 4th Leeds Symposium on Psychopathology is planned to take place on 20-21 September 1990 in the University of Leeds and at St James's University Hospital, Leeds. The topic will be 'Delusions and Awareness of Reality'. Further information: Professor A. C. P. Sims, Department of Psychiatry, Clinical Sciences Building, St James's University Hospital, Leeds LS9 7TF.

In collaboration with St George's Hospital Medical School (Section of the Psychiatry of Disability), the 8th two-day course on Death and Mental Handicap will be held on 13 and 20 November 1989 at the Postgraduate Centre, Barnet General Hospital. Course fee: $£ 70$ (including lunch and refreshments). Further information: Dr Lester Sireling, Psychiatric Unit, Barnet General Hospital, Herts EN5 3DJ (telephone 014405111 , extension 4616).

The Jewish Mental Health Group will be holding the following meetings (all at 8.30 p.m.) to provide a forum for Jews in the caring professions to discuss mental health care issues from a Jewish perspective: 21 September 1989 'Working with Holocaust Survivors'; 18 October 1989 'Anti-racist Policies at Work'; 22 November 1989 'Family Therapy with Orthodox Jewish Families'. Venues and further details: 014313916 or 016709081 (evenings).

A conference entitled Implementing Preventive Support Services for Schizophrenia, organized by the Prevention Research Project at MIND, will be held on 27 November 1989 at the Royal College of Physicians, London. The cost will be $£ 45.00$, including lunch. Further details: Research Secretary, MIND, 22 Harley Street, London WIN 2ED (telephone 01637 0741). 